Bahasa Indonesia Prima, Vol 2. No. 2. 2020

e-ISSN: 2684-6780

\title{
PENGUASAAN KOSAKATA ANAK USIA 6 TAHUN: STUDI KASUS PADA YUDHA
}

\author{
oleh: \\ Ike Trisnawati ${ }^{1}$, iketrisnawati02@gmail.com \\ Mujiyono Wiryotinoyo ${ }^{2}$, mujiyonowiryotinoyo@unja.ac.id \\ Herman Budiyono ${ }^{3}$, hermanbudiyono61@gmail.com \\ Program Studi Magister Pendidikan Bahasa dan Sastra Indonesia \\ Fakultas Pascasarjana \\ Universitas Jambi
}

\begin{abstract}
Abstrak-Pendekatan yang digunakan dalam penelitian ini adalah pendekatan kualitatif, dan jenis penelitian deskriptif. Penelitian deskriptif kualitatif dapat diartikan sebagai prosedur pemecahan masalah yang diselidiki dengan menggambarkan atau melukiskan keadaan subjek atau objek penelitian pada situasi sekarang berdasarkan fakta-fakta sebagaimana adanya. Teknik yang digunakan dalam mengumpulkan data adalah teknik simak, libat, cakap dan teknik catat. Analisis data dalam penelitian ini, menggunakan teknik analisis data model interaktif. Hasil penelitian ini kelas kata bahasa Indonesia yang dikuasai oleh Yudha anak usia 6 tahun sudah meliputi nomina, verba, adjektiva, adverbia, pronomina, numeralia, dan introgrativa. Dalam hal ini kelas kata nomina menempati posisi terbanyak yang dikuasai oleh Yudha. Untuk ruang lingkup kosakata, mayoritas ruang lingkup kosakata yang dikuasai Yudha masih berada pada tataran benda, aktivitas, keadaan atau hal-hal lain yang bersifat konkret. Merujuk pada hasil penelitian dapat disimpulkan bahwa jenis kosakata yang ditemukan bahwa kosakata Yudha sudah mencakup hampir seluruh kelas kata yang ada. Dari sepuluh kelas kata yang ada, sebagian besar kosakata anak sudah mencakup nomina, verba, adjektiva, adverbia, pronomina, numeralia, introgrativa. Dari hasil penelitian ini, kelas kata nomina menempati posisi terbanyak yang dikuasai oleh Yudha.
\end{abstract}

\section{Kata kunci: penguasaan, kosakata, anak usia 6 tahun}

Abstract-The approach used in this research is a qualitative approach and descriptive research type. Qualitative descriptive research can be defined as a problem-solving procedure that is investigated by describing or describing the state of the subject or object of research in the current situation based on the facts as they are. The techniques used in collecting data were listening, engaging, proficient and note-taking techniques. Data analysis in this study, using interactive model data analysis techniques.The results of this study that the Indonesian word class mastered 
by Yudha, a 6 year old child, includes nouns, verbs, adjectives, adverbs, pronouns, numeralia, and introgrativa. Referring to the results of the study, it can be concluded that the type of vocabulary found is that Yudha's vocabulary covers almost all existing word classes. Of the ten word classes, most of the children's vocabulary includes nouns, verbs, adjectives, adverbs, pronouns, numeralia, introgrativa. From the results of this study, the noun word class occupies the most position controlled by Yudha. For Yudha's vocabulary mastery process, feedback, imitation, and productivity are obtained. Suggestions to several parties such as parents, school teachers, further researchers.

\section{Keywords mastery, vocabulary, children aged 6 years}

\section{A. PENDAHULUAN}

Berbahasa tidak terlepas dari kosakata. Seiring dengan perkembangan anak dan pengalaman berinteraksi dengan lingkungannya, kosakata anak berkembang dengan pesat. Kosakata merupakan bagian penting dari bahasa. Penguasaan kosakata merupakan hal yang sangat penting dalam mencapai penguasaan bahasa. Penguasaan kosakata dapat mempengaruhi keterampilan berbahasa seseorang, semakin banyak kosakata yang dimiliki seseorang, maka semakin banyak pula ide dan gagasan yang dikuasainya.

Penguasaan kosakata merupakan bagian dari penguasaan bahasa, sebab jika seseorang menguasai bahasa berarti orang tersebut menguasai kosakata. Penguasaan kosakata yang ada pada diri seseorang dimulai sejak masih bayi dan ketika mampu merespon kata yang diucapkan orang lain. Pertumbuhan kosakata anak juga dipengaruhi oleh lingkungan sekitar anak. Semakin banyak kata yang diperoleh anak dari lingkungan, maka semakin banyak pula kosakata yang dimiliki anak. Jadi, kosakata yang dikuasai setiap anak berbeda antara usia yang satu dengan usia yang lain. Tarigan (2008:2) menjelaskan, penguasaan kosakata sangat diperlukan dalam setiap keterampilan berbahasa, baik itu menyimak, berbicara, membaca, maupun menulis.

Dalam

proses perkembangannya, semua anak manusia yang normal, paling sedikit memperoleh satu bahasa alamiah. Dengan kata lain, setiap anak yang normal atau yang tumbuh secara wajar, memperoleh suatu bahasa yaitu bahasa pertama atau bahasa ibu dalam tahuntahun pertama kehidupannya di dunia ini.

Penguasaan bahasa anak dimulai dari pengenalan dan penguasaan bunyi- bunyi bahasa. Setelah anak mengenal bunyi bahasa, selanjutnya anak mengenal bentukbentuk fonetik tertentu yang mengarah kepada pengenalan bunyi kata-kata. Sehingga pada akhirnya anak 
menguasai tataran bahasa layaknya orang dewasa. Dalam penguasaan bahasa, sejumlah linguis percaya bahwa kemampuan belajar bahasa sebagian berkaitan dengan program genetik yang memang khas bagi manusia. tidak ada mahluk-mahluk lain yang mempunyai sesuatu seperti kemampuan komunikatif kita sebagai insan manusia. Kenyataan ini dapat dilihat pada anak-anak yang mempunyai suatu keragaman dalam perkembangan linguistik mereka. Akan tetapi, lingkungan juga sangat berpengaruh dalam memberikan masukan-masukan terhadap penguasaan bahasa tersebut.

Poerwo (dalam Chaer 2009:230-236) menyatakan "tahap perkembangan bahasa bayi (kanakkanak) dapat dibagi dua, yaitu (1) tahap perkembangan artikulasi, dan (2) tahap perkembangan kata dan kalimat yang meliputi perkembangan kata pertama, kalimat satu kata, kalimat dua kata, dan kalimat lebih lanjut".

Perkembangan bahasa anak dalam masa pemerolehannya berjalan runtun dan beraturan dari tahap yang sederhana ke tahap yang lebih sempurna dan rumit. Perkembangan itu sesuai dan sejalan dengan perkembangan usia sang anak. Sehingga pada tahun-tahun perkembangannya, anak yang normal tumbuh secara wajar dan mengalami perubahan yang sesuai dengan runtutan usianya.
Yusuf (2014:170) menyatakan bahwa perkembangan bahasa anak 6 tahun berada pada masa keempat (2,66,0 ) yang bercirikan (1) anak sudah dapat menggunakan kalimat majemuk beserta anak kalimatnya, (2) tingkat berpikir anak sudah lebih maju, anak banyak menanyakan soal waktu sebabakibat melalui pertanyaan-pertanyaan: kapan, ke mana, mengapa, dan bagaimana.

Peneliti tertarik untuk meneliti penguasaan kosakata pada anak, karena masalah penguasaan kosakata anak sangat menarik dan sangat beragam, sehingga setiap penelitian diharapkan dapat memberikan pengetahuan baru bagi peneliti sendiri maupun orang lain. Informan dalam penelitian ini bernama Yudha tinggal di Jalan Mangkubumi No 62 RT 19 Kelurahan Budiman Talang Banjar Kota Jambi. Peneliti tertarik memilih anak tersebut karena saat peneliti melakukan pengamatan dapat dilihat bahwa kemampuan penguasaan kosakata yang didapatkannya sangat menarik perhatian peneliti. Berdasarkan pemaparan di atas melatarbelakangi peneliti mengkaji penguasaan kosakata anak usia 6 tahun: studi kasus pada Yudha sehingga orang tua dapat membangun hubungan komunikasi yang intensif dengan anak untuk membantu pertumbuhan kosakata anak sebagai bekal supaya anak dapat terampil berbahasa. Bagi guru sekolah dapat membantu meningkatkan penguasaan 
anak terhadap kosakata-kosakata verba yang bersifat operasional dan yang memiliki frekuensi tinggi dalam sebuah komunikasi.

\section{B. METODE PENELITIAN}

Penelitian ini merupakan penelitian dalam lingkup psikolinguistik yang menelaah penguasaan kosakata anak usia 6 tahun. Pendekatan dalam penelitian ini yaitu kualitatif, dan jenis penelitian deskriptif. Penelitian deskriptif kualitatif dapat diartikan sebagai prosedur pemecahan masalah yang diselidiki dengan menggambarkan atau melukiskan keadaan subjek atau objek penelitian pada situasi sekarang berdasarkan fakta-fakta sebagaimana adanya. Dalam penelitian ini dideskripsikan kosakata yang dikuasai anak usia 6 tahun. Data-data yang ada dideskripsikan juga ditafsirkan berdasarkan konteksnya. Data dalam penelitian ini adalah data verbal. Data verbal berwujud kosakata Bahasa Indonesia yang dikuasai Yudha anak usia 6 tahun yang diperoleh melalui observasi, dan rekaman yang dituangkan dalam bentuk catatan lapangan (transkrip). Sumber data dalam penelitian ini adalah anak dari kakak peneliti sendiri Yudha usia 6 tahun dan kedua orang tuanya. Teknik pengumpulan data menggunakan teknik observasi dengan metode simak libat cakap, teknik rekam, dan teknik catatan lapangan. Data yang diperoleh dianalisis dengan menggunakan teknik analisis model interaktif. Untuk menguji keabsahan data digunakan teknik Triangulasi. Teknik triangulasi yang dapat digunakan untuk melakukan uji keabsahan data yaitu (1) teknik sumber, (2) teknik metode, (3) teknik peneliti, (4) teknik teori. Dalam penelitian ini peneliti menggunakan teknik teori untuk uji keabsahan data penelitian.

\section{HASIL PENELITIAN DAN PEMBAHASAN}

penelitian terhadap penguasaan kosakata oleh Yudha, dapat diketahui bahwa anak usia enam tahun, yang duduk di bangku kelas 1 sekolah dasar telah dapat menguasai berbagai kosakata dari macam-macam kategori, meskipun dengan cara-cara (1) imitasi atau peniruan, (2) produktivitas, (3) umpan balik, (4) operasi. Kategori kata yang dapat dikuasai oleh Yudha meliputi, nomina, verba, pronomina, numeralia, adjektiva, adverbia, introgativa, demonstrativa, artikula, preposisi, konjungsi, kategori fatis, interjeksi.

\section{Nomina}

Berdasarkan hasil analisis didapatkan bahwa penguasaan kosakata oleh Yudha yang berupa nomina merupakan kelas kata yang paling banyak dikuasai oleh Yudha. Seperti kosakata mama, jam, roti, pintu, motor, ayah, susu, ibu, ayam goreng, ikan, sayur, bayam, sirup, sop, wortel, kentang, tempe, tahu goreng, tante, sendok, soto, abang, Adi, Wafa, Reihan, kerupuk, bantal, tv, Upin Ipin, 
dinosaurus, kaset, aku, adik, kakak, lauk.

\section{Verba}

Berdasarkan hasil analisis didapatkan bahwa penguasaan kosakata oleh Yudha yang berupa verba seperti, sarapan, istirahat, main, makan, minum, nonton, tidur, masak, sholat, belajar, baca buku, tunggu, nyanyi, pipis, menulis.

\section{Pronomina}

Dari hasil penelitian yang peneliti lakukan terhadap Yudha peneliti menemukan kosakata yang berupa pronomina yang dikuasai oleh Yudha seperti kata dimana, depan, sini, disini, ini, kemana. Dari data penelitian tersebut terlihat bahwa Yudha sudah menguasai kosakata bahasa Indonesia yang berupa pronomina dengan baik.

\section{Numeralia}

Dari hasil penelitian yang peneliti lakukan terhadap Yudha peneliti menemukan kosakata yang berupa numeralia yang dikuasai oleh Yudha seperti kata satu, dua, tiga, empat, tujuh, sembilan, sebelas, semua, tanggal. Dari data penelitian tersebut terlihat bahwa Yudha sudah menguasai kosakata bahasa Indonesia yang berupa numeralia dengan baik.

\section{Adjektiva}

Dari hasil penelitian yang peneliti lakukan terhadap Yudha, peneliti menemukan kosakata yang berupa adjektiva yang dikuasai oleh Yudha seperti kosakata ambil, lapar, haus, panas, minta, cakep, enak, pintar.

\section{Adverbia}

Berdasarkan hasil analisis didapatkan bahwa kelas kata yang dikuasai oleh Yudha yang berupa Adverbia seperti, kosakata sudah, iya, mau, nanti, sebentar, sama-sama, ada, januari, bukan, boleh, lagi.

\section{Interogativa}

Kelas Kata berupa interogativa. Dari hasil penelitian yang peneliti lakukan terhadap Yudha peneliti menemukan kosakata yang berupa introgrativa yang dikuasai oleh Yudha seperti kosakata apa. Dari data penelitian tersebut terlihat bahwa Yudha sudah menguasai kosakata bahasa Indonesia yang berupa interogativa dengan baik.

\section{Interjeksi}

Penguasaan kosakata berupa interjeksi. Dari hasil penelitian yang peneliti lakukan terhadap Yudha peneliti menemukan kosakata yang berupa interjeksi yang dikuasai oleh Yudha seperti kosakata halo.

Proses Penguasaan Kosakata Pada Yudha Anak Usia 6 Tahun

Berdasarkan data hasil penelitian terhadap penguasaan kosakata oleh Yudha, dapat diketahui bahwa anak usia enam tahun, yang duduk di bangku kelas 1 sekolah dasar telah dapat menguasai berbagai kosakata dari macam-macam kategori, meskipun dengan cara-cara (1) imitasi atau peniruan, (2) produktivitas, (3) umpan balik, (4) operasi. Dalam penguasaan bahasanya, Yudha sudah menggunakan ke empat proses 
tersebut. Hal ini dapat dilihat dari tuturan berikut:

1) Mama: Yudha bangun mandi, nanti terlambat ke sekolah Yudha: Sudah jam berapa, Ma? Mama: Sudah jam 6, ayo bangun Yudha: Iya

Nomina jam, mama, adverbia sudah, iya merupakan hasil dari umpan balik yang diberikan oleh mamanya. Yudha menguasai kata-kata tersebut setelah diberikan umpan balik dari ibunya dengan pertanyaan-pertanyaan yang membuat Yudha menguasai kosakata tersebut.Contoh lain:

2) Mama: Yudha, tidur siang dulu yuk nak

Yudha: Nanti, Yudha mau nonton Mama: Ya, sekarang tidur siang dulu, nanti sore bangun tidur nonton lagi

Yudha: Iya, Mama

Nomina (Mama, Yudha), verba (nonton), adverbia (nanti, mau, dan iya). merupakan hasil dari umpan balik yang diberikan oleh mamanya. Berupa pertanyaan-pertanyaan yang membuat Yudha mampu mengungkapkan apa yang ada dipikirannya, seperti kata nanti, mau, nonton. merupakan pengungkapan terhadap penolakan Yudha terhadap mama yang menyuruh Yudha untuk segera tidur siang.

Selain umpan balik, Yudha menguasai kosakata Bahasa Indonesia dengan cara imitasi atau meniru apa yang diucapkan oleh lawan bicaranya. Seperti terlihat pada contoh berikut:
3) Mama: Pagi anak mama

Yudha: Pagi, Ibu Luky

Mama: Pagi, Sayang

Yudha: Mama

Mama: Cakep anak Mama hari ini yah

Yudha: Cakep la

Mama: Iya, Yudha anak Mama yang paling cakep

Yang diucapkan oleh lawan bicaranya, seperti kata pagi dan cakep. Kata tersebut diperoleh Yudha dengan meniru perkataan mamanya. Contoh lain:

4) Mama: Yudha, sini nak

Yudha: Apa, Ma?

Mama: Ada film kartun kesukaan Yudha nih

Yudha: Upin Ipin ya, Ma? Dimana?

Mama: Iya, di TV, nak

Yudha: TV (sambil lari ke ruang TV)

Mama: Ayo sini nanti habis loh filmnya Upin Ipinnya?

Yudha: Betul... betul... betul

Dalam proses penguasaan kosakatanya Yudha masih sering meniru kata-kata yang diucapkan oleh lawan bicaranya, seperti kata Betul. Kata tersebut diperoleh Yudha dengan meniru perkataan dari film kartun kesukaan Yudha yang di tonton yaitu Upin dan Ipin.

Selain imitasi, Yudha menguasai kosakata Bahasa Indonesia dengan cara produktivitas dan operasi. Seperti terlihat pada contoh berikut: 
5) Yudha: Ma, Yudha lapar

Mama: Ya, Mama ambilin nasinya, mau pakai lauk apa nak?

Yudha: Ayam goreng

Mama: Tunggu sebentar ya

Dalam percakapan diatas terlihat Yudha terlihat proses produktivitas dalam proses penguasaan kosakata Yudha. Kosakata yang diperoleh Yudha merupakan hasil dari produktivitas Yudha yang menyatakan bahwa ia lapar dan meminta makan kepada mamanya.

\section{SIMPULAN}

Berdasarkan hasil penelitian dan pembahasan yang telah dilakukan dapat diambil kesimpulan sebagai berikut:

1. Kosakata yang dikuasai oleh Yudha dari segi kelas kata bahasa Indonesia disimpulkan bahwa kosakata Yudha sudah mencakup hampir seluruh kelas kata yang ada. Dari sepuluh kelas kata yang ada, sebagian besar kosakata anak sudah mencakup nomina, verba, adjektiva, adverbia, pronomina, numeralia, introgrativa, interjeksi, dan demonstrativa. Dari hasil penelitian ini, kelas kata nomina menempati posisi terbanyak yang dikuasai oleh Yudha.

2. Proses penguasaan kosakata Yudha diperoleh umpan balik, imitasi, produktivitas, yang mana dalam penelitian ini Yudha sudah bisa menguasai kosakata dengan baik.

\section{SARAN}

Dari hasil penelitian ini dapat disarankan sebagai berikut:

1. Bagi Orangtua

Bagi orangtua disarankan supaya dapat membangun hubungan komunikasi yang intensif dengan anak untuk membantu pertumbuhan kosakata anak sebagai bekal supaya anak dapat terampil berbahasa.

2. Bagi guru sekolah

Bagi guru sekolah disarankan dapat membantu meningkatkan penguasaan anak terhadap kosakata-kosakata verba yang bersifat operasional dan yang memiliki frekuensi tinggi dalam sebuah komunikasi.

3. Bagi peneliti selanjutnya

Bagi peneliti lain yang ingin memperdalam penelitian ini dapat meneliti mengenai hubungan variabel usia, jenis kelamin, atau kondisi lingkungan keluarga terhadap penguasaan kosakata anak secara lebih terfokus.

\section{DAFTAR RUJUKAN}

Alwi, H, dkk. 1999. Tata Bahasa Baku Bahasa Indonesia. Jakarta: Balai Pustaka

Chaer, A. 2009. Psikolinguistik. Jakarta: Rineka Cipta.

Damanhuri. 2014. Penguasaan Kosakata kedwibahasaan Antara Bahasa Sunda dan Bahasa Indonesia Pada Anak-anak (Sebuah Analisis 
Deskriptif-Komparatif). Tesis S2.: $\quad$ FKIP Universitas Singaperbangsa Karawang.

Dardjowidjojo, $\quad$ S. 2003. Psikolinguistik. Jakarta: Yayasan obor Indonesia.

Hurlock. 1978. Perkembangan Anak. Terjemahan oleh Meita Sari dan Musli Chan Zarkasih. Tanpa tahun. Jakarta: Erlangga.

Kridalaksana, H. 2005. Kelas Kata Dalam Bahasa Indonesia. Jakarta: Gramedia. . 2007. Pembentukan Kata dalam Bahasa Indonesia. Jakarta: Gramedia.

Mahsun. 2007. Metode Penelitian Bahasa. Jakarta: Raja Grafindo Persada.

Mismah. 2014. Pemerolehan Kalimat Bahasa Indonesia Anak Prasekolah Usia 3-6 Tahun Pada PAUD Darun Naghom Bengkel Kabupaten Lombok Barat. Tesis S2. Universitas Mataram. Nusa Tenggara Barat.

Moeliono. 2008. Kamus Besar Bahasa Indonesia Edisi Keempat. Jakarta: Gramedia.

Monks, F.J, dkk. 2004. Psikologi Perkembangan. Yogyakarta: Gajah Mada University Press.
Poerwadarminta, W.J.S. 1984. Kamus Umum Bahasa Indonesia. Jakarta: Balai Pustaka.

Rahmawati. 2012. Penguasaan Kosakata Bahasa Indonesia Anak Prasekolah. Skripsi. Malang: FS Universitas Negeri Malang.

Ramlan. 1983. Morfologi Suatu Tinjauan Deskriptif. Yogyakarta: Karyono.

Suryanirmala. 2014. Penguasaan Kosakata Bahasa Asing Pada Anak TK Dengan Metode Drilliing Verbalisasi Kata. Tesis S2. Universitas Mataram.

Sinaga, A. Tanpa tahun. Teori Belajar Bahasa Jambi: FKIP UNJA.

Sugiono. 2010. Metode Penelitian Kuantitatif, Kualitatif, dan $R D$. Bandung: Alfabeta.

Tarigan, H. G. 1988. Pengajaran Pemerolehan Bahasa. Bandung: Angkasa.

Wiryotinoyo, M. 2010. Implikatur Percakapan Anak Usia Sekolah Dasar. Malang: UM Press.

Yusuf, S. 2006. Psikologi Perkembangan Anak dan Remaja. Bandung: PT. Remaja Rosdakarya. 